\title{
TOPICs

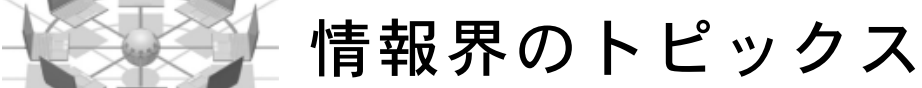 \\ Topics of the Information Community
}

\section{Googleが本の無料ダウンロードサービスを開始}

Googleは, パブリックドメインに属する古典文 学などの作品の, 無料ダウンロードサービスを開 始したことを，8月30日に発表した。その中には， ダンテの「地獄篇」や「イソップ物語」, ニュー トンの「自然哲学の数学的諸原理（プリンキピ ア）」などが含まれる。Google Book Searchでは， これまでは著作権の切れた本についても, オンラ インで1ページずつ読むことしかできなかったが, PDFファイルをダウンロードあるいはプリントす ることを可能にしたものである。Googleは，ポリ シーを変更した理由を, 利用者と協力図書館双方 からの要望を取り入れたためであるとしているが,

ライバルプロジェクトである Open Content Alliance （OCA）のダウンロードポリシーに対抗したもの と見られている。さらに，協力図書館のひとつで あるミシガン大学が, MBooksの中から著作権に問 題のない作品の公開を始めたことも, 影響してい るであろう。MBooksには, Googleによってデジタ ル化されたミシガン大学の蔵書数十万冊が含まれ ている。

著作権切れの作品の公開を目指すプロジェクト は他にも多数あるが, それらと比べてGoogle Book Searchは,フルテキストを検索でき,カバー範囲 が広いという点では優位に立つ。例えば，グーテ ンベルクプロジェクト（Project Gutenberg）は, 約 19,000の古典作品へのアクセスを提供するが, テ キストフォーマットのみであり, キリスト教の古 典文献を集めたChristian Classics Ethereal Library は，テキストとPDFの両フォーマットがあるが, 主題が限定されている。しかしGoogleは，OCAな どとは異なり，たとえデジタルファイルがあると しても, ダウンロードはアナログ・イメージファ イルに限定しており，ダウンロードされたものは 検索することができない。また, PDFファイルの 解像度が低いため, 読みづらいとの批判がある。 Googleはダウンロードが可能となった作品として, 上述の3作品を例として挙げているが, 現在パブ リックドメインを占めている作品の大半はあまり
有名ではないものである。ダウンロード可能な作 品を検索するには，検索画面で「Full View Books」 ボタンを選択するようにとの指示があるが，検索 結果として得られた作品のすべてがダウンロード できるわけではない。現在は, ダウンロード可能 な作品のみを検索する方法がないのも問題とされ ている。さまざまな批判もあるとはいえ, Google Book Searchが一歩前進したと言ってよいであろう。 (http://www.google.com/press/annc/booksearch_ download.html)

(http://www.infotoday.com/newsbreaks/nb0609052.shtml)(accessed 2006-09-09)

\section{Oxford Openサービス開始後一年の結果}

2005年7月に, ハイブリッドなオープンアクセス （OA）ジャーナルのプログラム, Oxford Openを開 始したOxford University Press社が，この一年の結果 を発表した。Oxford Openでは，著者は2,800ドルあ るいは 1,500 ポンドを支払うことにより，出版後直 ちに研究論文をインターネット上で無料公開する ことを許され，その際にピアレビュー後の論文にす るか, 出版原稿にするかを選択することができると いう，著者支払いによるOA出版モデルである。一 年の間に, このOAモデルの下に発表された論文は 全部で約 400 点あり, それらの論文は対象ジャーナ ル49誌のうち36誌に掲載されたが, OAの割合は分 野により大きな差が見られた。OA論文の大半はラ イフサイエンスに属するもので, この分野の著者 は, 約 $10 \%$ がOAを選択した。分子・計算生物学分 野を扱うライフサイエンス 3 誌においては，OA論文 は20\%を超えた。特に，「Bioinformatics」誌は2006 年のOA論文は $50 \%$ を超える数字を示した。他方, 医学・公衆衛生学は約 $5 \%$, 人文科学・社会科学は 約3\%にすぎない。OA出版モデルを選んだ著者の $80 \% に は$, 所属機関が投稿雑誌を購読しているこ とにより, ディスカウント料金, 1,500 ドルあるい は 800 ポンドが適用された。OA論文の数とそのオ ンライン利用状況により，2007年から毎年改定さ 
れるという取り決めに従い，「Bioinformatics」， $\lceil$ Carcinogenesis」,「Human Molecular Genetics」 3 誌の 2007 年オンライン購読料は改定される。 Oxford University Press社は，49誌についてはOxford Openを2007年も継続すると述べている。

(http://www.oxfordjournals.org/oxfordopen/)(http:// www.oxfordjournals.org/news/oa_report.pdf)(accessed 2006-09-09)

\section{もうひとつのブックサーチプロジェクト LibreDigital Warehouseが登場}

NewsStand 社はLibreDigital 部を新設して， LibreDigitalWarehouseと名付けたサービスを開始し たと発表した。出版社と書店が, 自分たちのWeb サイト上で検索可能な本の内容を表示できるよう にするためのサービスである。利用者が本の内容 を検索し, テキストや図の一部を見ることができ るのは, Google Book Searchと同じである。しかし， Google Book Searchと異なり, LibreDigital Warehouseでは, 出版社はどのページを利用者に見 せるか, どのぺージは絶対に見せないか（例えば， 小説の最後の3ページ），本の何パーセントを見せ るか, などをタイトルごとに決めることができる。 それだけではなく, 出版社のサイト, 著者のサイ 卜, 小売店のサイト, それぞれにおいて表示する 部分を変えることも, プリントやコピーペースト を制限することも可能で, Googleの図書館蔵書ス キャンプログラムに不満を感じている出版社を狙っ ている。LibreDigitalによれば, 多くの出版社と話 し合っているが, 新しいサービスは歓迎を受けて おり, 間もなく複数の出版社の参加を発表できる だろうとのことである。現在このサービスに参加 している唯一の出版社であるHarperCollins が提供 するBrowse Insideは，3,400タイトルを提供してお り, その数を最終的には1万タイトルにする予定で ある。ただし, 今はブラウズができるだけで, 検 索機能は数か月待たなければならない。

LibreDigital は，著作権を保有する本をWebで管 理する方法を出版社に与えることは, 出版界とGoogle 間の緊張を緩和するのに役立つだけでなく, 出版 社が書店をサポートするのにも役立つと強調して いる。

(http://www.newsstand.com/corporate/press.cfm) (http://www.harpercollins.com/footer/release.aspx?id= $477 \&$ year $=2006$ ) (http://www.infotoday.com/newsbreaks/nb0608281.shtml)(accessed 2006-09-09)

\section{Googleが今度はGoogle News Archive Searchを 開始}

Googleは9月6日, 新しくGoogle News Archive Searchを開始すると発表した。インターネット利 用者が新聞, 雑誌などのアーカイブを検索し, 場 合によっては 200 年以上前の資料までさかのぼって 八手するのを助けるサービスで, 利用者は検索後, 有料あるいは無料出版社サイトへ導かれる。Google は出版社のデータベースを独自にインデックスす る。このサービスに参加している出版社の数は発 表されていないが, The Wall Street Journal, The New York Times, The Washington Post, Time, Guardian, Factiva, Lexis-Nexis, HighBeam Research, Thomson Galeの各社が含まれているこ とが明らかにされている。このサービスは, 数年 来, 出版社側から提供を求められていたという点 でGoogle Book Searchとは対照的である。含まれる データベースは, スパイダー（Web巡回プログラ ムによってページを探す）できなかったり，イン デックスできなかったため, これまで標準的な検 索エンジンでは探すことができなかった情報であ る。ただし, HighBeamの場合, 3,300点の出版物, 4,000万のドキュメントの一部は無料で利用できる が, 無料でないものについては, へッドラインと 冒頭の600字しか表示されない。全部を見るために は，20ドル／月か, 100 ドル／年を払わなければな らない。Time誌は全部を検索することが可能であ り，既に1923年までさかのぼり，30万件の記事を 無料で読むことができるようになっている。The New York Time紙やThe Washington Post紙などは, 検索の結果, 記事購入のサイトに導かれる。検索 の際には, Archive全体を対象とすることも, 新聞 /雑誌を特定することもできる。

Googleはこのサービスから直接収入を得ること はないが, このサービスがGoogleのオンライン決 済代行サービス（checkout payment）システムにリ ンクすることを期待している。 (http://news.google.com/archivesearch) (http://money.cnn.com/2006/09/06/technology/bc. media.google.history.reut/index.htm? cnn=yes) (accessed 2006-09-09) 


\section{Web of Scienceが看護関連誌収録を強化}

看護学に関する研究の注目度が世界的に高まっ ている傾向を受けて, トムソンコーポレーション 社は, 2006年末までに, 同社が提供する学術文献 データベースWeb of Scienceに収録する看護雑誌数 を今までのほぼ2倍に増加する計画を発表した。収 録誌の選定に当たっては，アメリカ医学図書館協 会（MLA：Medical Library Association）内の看護お よび関連保健資料部門（NAHRS：Nursing and Allied Health Resource Section）が協力している。同部門 の代表Melody Allisonは, NAHRSの看護文献マッピ ング作業部会を代表して, ジャーナル評価の指標 として重要視される同データベースへの収録増加 によって, 看護分野の学術誌の影響力が高まるこ とへの期待を表明し, NAHRSの計量書誌学的調査 において高いインパクトを示した雑誌の多くが今 回の追加文献リストに加えられたことを述べている。 (http://scientific.thomson.com/press/2006/8341223/) (accessed 2006-09-12)

\section{SNS利用トラブルへの自己防衛手段を提言する図 書館員}

米国で検討されている未成年者の図書館でのソー シャルネットワーキングサイト（SNS）接続規制 に関する法案「Deleting Online Predators Act （DOPA，オンライン性犯罪者排除法）」について， 前号本欄で紹介したように米国図書館協会（ALA） は反対の意を表明していたが, 同法の問題点につ いて論じたイリノイ州図書館協会Robert P. Doyleに よる記事「The Current Legislative Challenge: DOPA and the Participation Gap（最新の法的課題：DOPAと 参加機会の格差）」が，ALAのDOPA情報サイトに 資料として追加された。

Doyleの記事はイリノイ州図書館協会の機関紙 The ILA Reporter 10月号（Volume XXIV, Issue 5）に 初出掲載されたものであるが, SNSの接続制限が 若年者の社会参加の機会を減ずるものであるとい
う観点から, SNS 研究を専門とする比較メディア 学の専門家や, 政策研究シンクタンクで教育・家 庭政策に携わる識者らの意見を紹介している。接 続の規制に代わる方法として, SNSに関する利用 者教育の重要性を提示するとともに, 保護者向け · ティーンズ向けにそれぞれ，SNS利用に際して注 意すべき点や対処方法が, セーフティーガイドと して箇条書きにまとめられている。DOPAに関する 論点, インターネットの安全な利用に向けたイリ ノイ州図書館協会のアクションプランも表明され ており，法規制に代わる対処によって，未成年者 のSNS 利用問題を解決しようとする図書館側の姿 勢を概観できる一資料となっている。 (http://www.ala.org/ala/oif/ifissues/ onlinesocialnetworks. htm) (http://www.ila.org/pub/reporter/vo124no5.pdf) (accessed 2006-09-12)

\section{European Archive立ち上げの正式発表}

Open content Alliance（OCA）の加盟メンバーでも あり, 既に映像・録音・Webサイトなどのアーカ イブコンテンツを登載して運営されている 「European Archive」であるが，9月末にオランダ で行われるメディアコンテンツの国際会議「PICNIC '06: Cross Media Week」において, 初日のレセプショ ンプログラムの一部として, 発足の正式発表が行 われることが告知された。発表と併せて, 米国の Internet Archive から基調講演者を迎えたセミナー $\ulcorner$ Avoiding the Digital Memory Loss」も行われる。

European Archiveは，フランス国立図書館のWeb アーカイビングプロジェクトやInternational Internet Preservation Consortiumなどに携わってきたWebアー カイビングの専門家Julien Masanèsが代表を務めて おり，インターネットを通じてヨーロッパの文化 資源へのユニバーサルアクセスを提供することを 目指している。 (http://www.europarchive.org/)(http://www.picnic06. org/)(accessed 2006-09-12) 